\title{
Perchlorate in drinking water around rocket manufacturing and testing facilities and firework manufacturing sites in Kerala, India
}

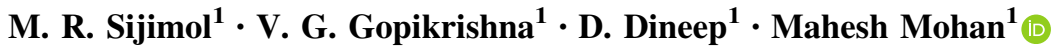 \\ ${ }^{1}$ School of Environmental Sciences, Mahatma Gandhi University, Kottayam, Kerala, India
}

Received: 5 October 2016/Revised: 28 February 2017/Accepted: 2 March 2017/Published online: 13 March 2017

(c) Joint Center on Global Change and Earth System Science of the University of Maryland and Beijing Normal University and Springer-Verlag Berlin Heidelberg 2017

\begin{abstract}
Perchlorate is used as an oxidizing agent in rocket propellants, fireworks, munitions, etc. This results in perchlorate contamination of drinking water sources in the nearby areas. The present study was carried out in Kerala, southwest coast of India, where exist rocket propellant manufacturing site (Ammonium Perchlorate Experimental Plant), rocket propellant testing facility (Thumba Equatorial Rocket Launching Station) and several fireworks manufacturing sites. Perchlorate contamination in drinking water was monitored during post-monsoon, pre-monsoon and monsoon seasons around these sites. Liquid chromatography-mass spectrometry was used for perchlorate quantification in drinking water. Mean perchlorate in drinking water ranged from 1.03 to $3760.16 \mathrm{ppb}$ in postmonsoon, $<6$ to $5094.87 \mathrm{ppb}$ in pre-monsoon and 13.99 to $601.28 \mathrm{ppb}$ in monsoon. The perchlorate contamination is found to be varied with season, site and the type of drinking water.
\end{abstract}

Keywords Pollution · LCMS · Health · Thyroid

\section{Introduction}

Perchlorate is a colorless, odorless chemical, and its salts are highly soluble and mobile in water (Motzer 2001; ATSDR 2008; Sanchez et al. 2005). The

Electronic supplementary material The online version of this article (doi:10.1007/s40974-017-0055-x) contains supplementary material, which is available to authorized users.

Mahesh Mohan

mahises@gmail.com perchlorate anion $\left(\mathrm{ClO}_{4}\right)$ in water remains highly stable and unreactive and may take decades to degrade (Siglin et al. 2000; Srinivasan and Viraraghavan 2009; Motzer 2001). The major sources are rocket propellants, fireworks manufacturing and display, blasting agents, military munitions, etc. as it is a good oxidizing agent (Tikkanen 2006; Sijimol and Mohan 2014; Sugimoto et al. 2012). Perchlorate could reach the aquatic ecosystem by a number of ways such as runoff and direct deposition (Logan 1998). Perchlorate contamination was noticed in rain water, raw and treated drinking water, groundwater, bottled water, open well and surface water resources from different parts of the world (McLaughlin et al. 2011; Anupama et al. 2012; Snyder et al. 2005).

The perchlorate could enter human body through drinking and may get either eliminated through urine (Cheng et al. 2008) or transmitted to the thyroid gland, saliva (Kannan et al. 2009), placenta (Steinmaus et al. 2010) or mammary glands (Dohan et al. 2007) through sodium iodide symporter (NIS). It is one of the most potential inhibitors of $\mathrm{T}_{4}$ release (Hornung et al. 2010). It inhibits uptake of iodide at the cellular level (Soldin et al. 2001; Kirk 2006). Hence, it is important to study the perchlorate contamination of drinking water which will help in assessing the potential risk. Risk assessment of perchlorate among the inhabitants of the contaminated place can be done only by assessing the seasonal variation. The present study assessed the temporal variation of perchlorate around rocket propellant manufacturing and testing facilities and selected firework manufacturing sites in Kerala, India, which is not yet reported. 


\section{Materials and methods}

\subsection{Study area and sample collection}

The samples were collected seasonally (post-monsoon, October-January; pre-monsoon, February-May; and monsoon, June-September) from the selected locations of Kerala, southwest coast of India (Fig. 1). The major perchlorate contamination sources such as Ammonium Perchlorate Experimental Plant (APEP), where 800 tones of ammonium perchlorate is manufactured per year (site 1); Thumba Equatorial Rocket Launching Station (TERLS) (site 2); and firework manufacturing sites-two firework manufacturing sites from central part of Kerala (sites 3 and 4)—were selected to monitor perchlorate contamination. A control (site 5) was also selected where $5 \mathrm{~km}$ surrounding area is free from any perchlorate handling activities. Well water (total-87 samples; 18 from sites 1 to 4 and 15 from site 5) and tap water (9 samples: 3 samples each from sites 1, 2 and 4) samples were collected in sterile polypropylene bottles and filtered immediately using $0.2-\mu \mathrm{m}$ nylon membrane filter paper. There is a possibility for perchlorate to undergo microbiological degradation under anaerobic conditions. Hence, the samples were stored in the bottle by keeping one-third portions empty that will reduce the potential for degradation by any remaining anaerobic organisms. In the laboratory, samples were kept below $4{ }^{\circ} \mathrm{C}$ until analysis. The analysis was completed within 28 days after collection (EPA 331.0).

\subsection{Parameters analyzed}

Apart from perchlorate, parameters such as $\mathrm{pH}$, electrical conductivity (EC), total dissolved solids (TDS), salinity (SAL), anions such as chloride $\left(\mathrm{Cl}^{-}\right)$, nitrate $\left(\mathrm{NO}_{3}{ }^{-}\right)$, sulfate $\left(\mathrm{SO}_{4}{ }^{2-}\right)$ and chlorate $\left(\mathrm{ClO}_{3}{ }^{-}\right)$, and cations such as ammonium $\left(\mathrm{NH}_{4}{ }^{+}\right)$, sodium $\left(\mathrm{Na}^{+}\right)$, potassium $\left(\mathrm{K}^{+}\right)$, calcium $\left(\mathrm{Ca}^{2+}\right)$ and magnesium $\left(\mathrm{Mg}^{2+}\right)$ were measured.

\subsection{Instrumental analysis}

$\mathrm{pH}$ was measured using digital $\mathrm{pH}$ meter. EC, TDS and salinity of the samples were analyzed using conductivity meter. Ion chromatography (Dionex 1100) was used for the detection of anions (except chlorate and perchlorate) and cations. Perchlorate and chlorate were detected by LCMS (Shimadzu 2020) (EPA Method 331.0). The column used was Dionex AS-21 and methylamine as eluent. Selective ion monitoring mode was applied for the quantification of perchlorate. Perchlorate has an $\mathrm{m} / \mathrm{z}$ of 99 and an isotopic $\mathrm{m} /$ $z$ of 101 . Groundwater usually contains an ion of sulfate $\left(\mathrm{H}^{34} \mathrm{SO}_{4}\right)$ at $\mathrm{m} / \mathrm{z}$ 99. Both $\mathrm{m} / \mathrm{z} 99$ and $\mathrm{m} / \mathrm{z} 101$ were measured, and peak area having a ratio of $\mathrm{m} / \mathrm{z} 99$ to $\mathrm{m} / \mathrm{z} 101$ as 3:1 $\pm 25 \%$ was accepted as of perchlorate and $\mathrm{m} / \mathrm{z} 101$ was selected for quantification. Chlorate was detected and quantified at $\mathrm{m} / \mathrm{z}$ 83. For perchlorate, method detection limit was $2 \mathrm{ppb}$ and limit of quantification was $6 \mathrm{ppb}$, and for chlorate method detection limit was $4 \mathrm{ppb}$ and limit of quantification was $6 \mathrm{ppb}$.

\section{Results and discussion}

\subsection{Temporal variation of perchlorate}

Perchlorate was detected in drinking water samples in all the seasons (except during pre-monsoon at site 3 firework manufacturing site) (Table 1). At sites 1 and 2, mean perchlorate levels in all the seasons were more than $24.5 \mathrm{ppb}$. At site 1, perchlorate in drinking water ranged from $<6 \mathrm{ppb}$ to $24,132.71 \mathrm{ppb}$ during post-monsoon, 19.2 to $32,602.6 \mathrm{ppb}$ during pre-monsoon and 30.18 to $4171.78 \mathrm{ppb}$ during monsoon. The range of perchlorate in water samples from TERLS (site 2) ranged from 8.09 to $4913.77 \mathrm{ppb}$ during post-monsoon, 14.68 to $3133.05 \mathrm{ppb}$ during pre-monsoon and 8.06 to $410.86 \mathrm{ppb}$ during monsoon season. Firework manufacturing sites also showed variation in perchlorate content during different seasons. The values ranged from $<6$ to $369.38,16.22$ to 51.74 and $<6$ to $35.08 \mathrm{ppb}$ during post-monsoon, pre-monsoon, monsoon, respectively, at manufacturing site (site 4), whereas in site 3 the maximum variation was observed during monsoon ( $<6$ to $40.66 \mathrm{ppb}$ ). Perchlorate was not found in control site during all the seasons.

The perchlorate concentration at various sites during different seasons is presented in Fig. 2. Very high values were observed at sample 1 of site 1 during all the seasons $(24,132.71,32,602.6,4171.78 \mathrm{ppb})$ and sample 2 of site 2 during post-monsoon $(4913.77 \mathrm{ppb})$. High perchlorate concentrations were observed for sites 1 and 2 during all the seasons compared with other sites. During the premonsoon and post-monsoon, high variability was observed for site 1 and site 2, respectively. However, site 3 showed high variability in post-monsoon. All the sites showed the presence of perchlorate during the monsoon and postmonsoon seasons. The average values showed that at site 1 , the maximum concentration was noted during pre-monsoon followed by post-monsoon. The results clearly indicate that the industrial sites (sites 1 and 2) are highly contaminated than the firework manufacturing sites (sites 3 and 4). This might be due to the high usage of materials during the operations. In the case of tap water, perchlorate value at site 1 ranged from $19.2 \mathrm{ppb}$ during pre-monsoon to $39.37 \mathrm{ppb}$ during monsoon and below detectable limit (BDL) during post-monsoon. At site 3, only monsoon 


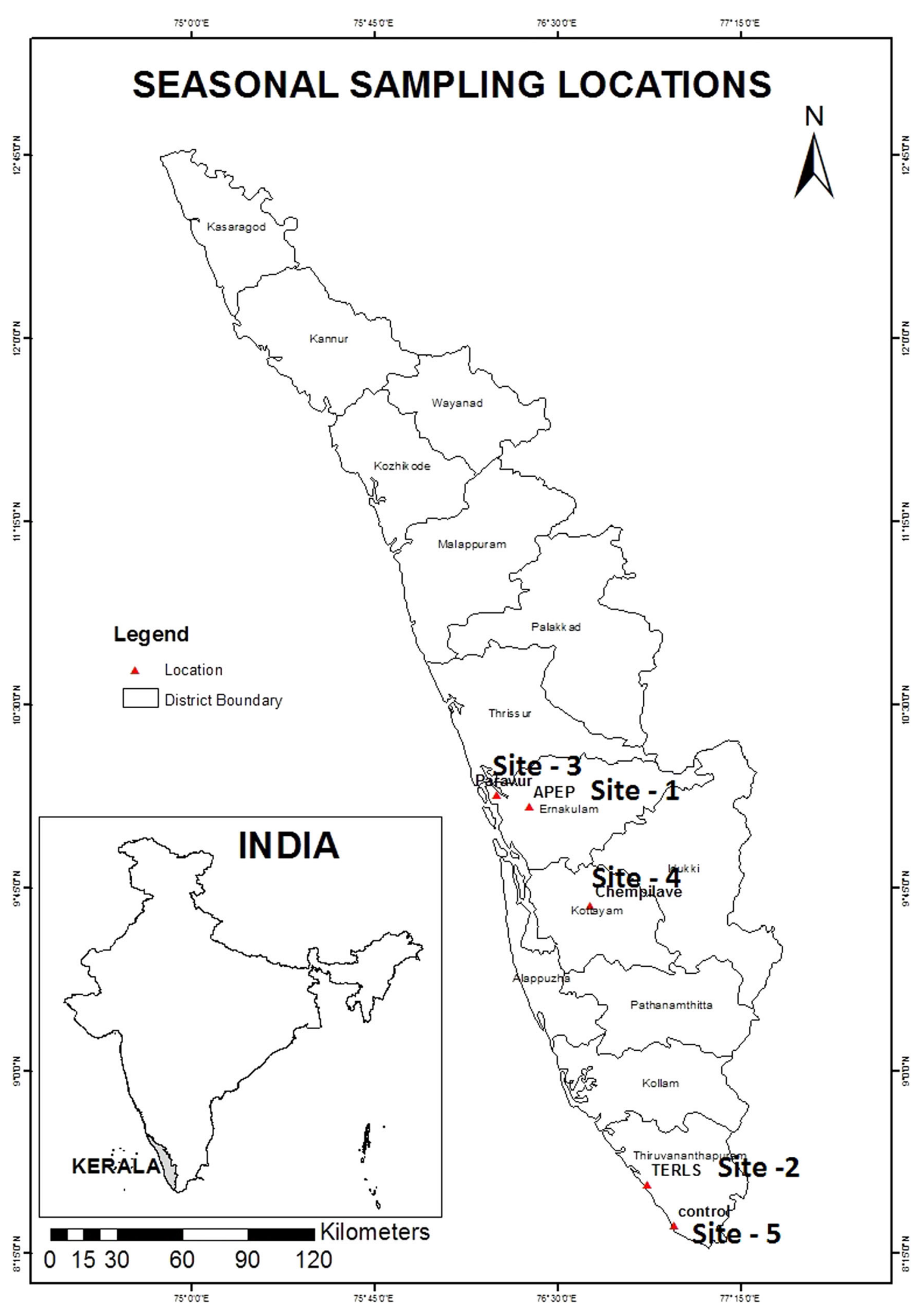

Fig. 1 Location map with sampling sites 
Table 1 Mean perchlorate content in the study area during different seasons

\begin{tabular}{lll}
\hline Site & Season & Mean perchlorate (in ppb) \\
\hline Site 1 & POM & $3760.16 \pm 9007.53$ \\
& PRM & $5094.87 \pm 12,159.55$ \\
Site 2 & MON & $601.28 \pm 1360.64$ \\
& POM & $640.4 \pm 1727.04$ \\
Site 3 & PRM & $468.57 \pm 1174.97$ \\
& MON & $80.61 \pm 146.04$ \\
& POM & $1.03 \pm 2.72$ \\
Site 4 & PRM & BDL \\
& MON & $17.76 \pm 14.25$ \\
& POM & $61.56 \pm 150.80$ \\
Site 5 & PRM & $25.42 \pm 13.44$ \\
& MON & $13.99 \pm 16.90$ \\
& POM & BDL \\
& PRM & BDL \\
\hline
\end{tabular}

$B D L$ below detectable limit

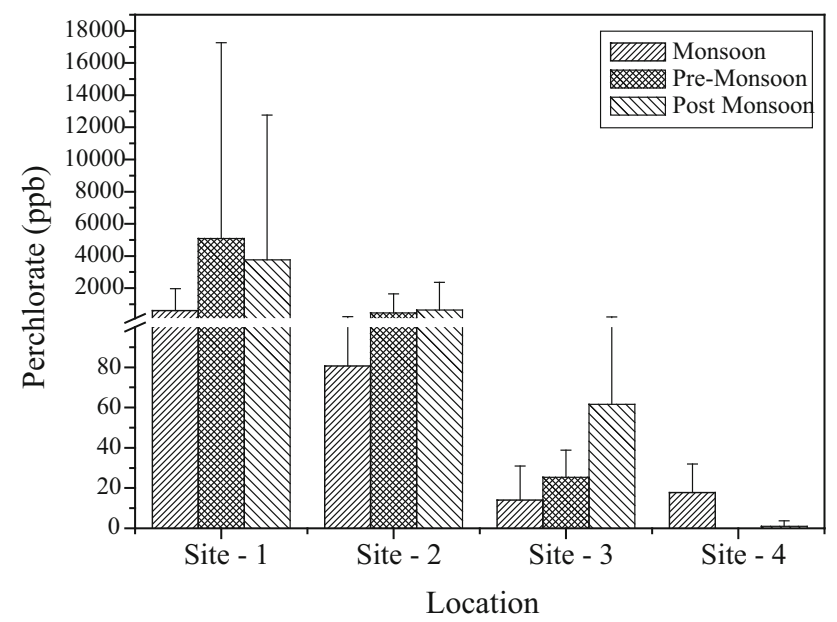

Fig. 2 Perchlorate content in water samples during various seasons

sample had a perchlorate of $20.72 \mathrm{ppb}$. Tap water from site 2 was found to be contaminated with perchlorate during all seasons, ranging from 8.09 to $25.08 \mathrm{ppb}$. The results of other water quality parameters $(\mathrm{pH}, \mathrm{EC}, \mathrm{TDS}$, salinity, chloride, nitrate, sulfate, calcium, magnesium, sodium, potassium and chlorate) are given in Table 2. All the parameters except a very few parameters of sites 1 and 2 are within the permissible limit (WHO 2011; BIS 2012). During pre-monsoon, the high concentration was observed for chlorate (site 1), nitrate and calcium (site 2), whereas in post-monsoon and monsoon, sulfate and chlorate (site 2) and nitrate, respectively. Chlorate was high during the nonmonsoon seasons for both industrial sites.

\subsection{Correlation of perchlorate with other parameters}

The interrelationship between perchlorate and other water quality parameters was tested with Pearson's correlation analysis. Water samples analyzed from APEP in all seasons showed significant positive correlation between perchlorate and chlorate $(p=0.01)$. Correlation analysis of samples from APEP further showed positive significant correlation between perchlorate and sodium, nitrate and sulfate during post-monsoon and with $\mathrm{pH}, \mathrm{EC}$, TDS, SAL, chloride, nitrate and magnesium during monsoon $(p=0.01)$. Samples from TERLS showed highly significant correlation between perchlorate and chloride during post-monsoon $(p=0.01)$, and no other parameters showed correlation with perchlorate in any of the seasons. At Paravur, perchlorate in water samples showed significant positive correlation with magnesium during post-monsoon and with sulfate during pre-monsoon $(p=0.01)$. Perchlorate was significantly correlated $(p=0.01)$ with sulfate and ammonium during post-monsoon at fireworks manufacturing site (site 4). A general correlation was done combining all seasons and all sites. It showed that perchlorate is correlated with chlorate and with no other parameters. Variation of correlation in different sites may be due to the change in general flushing of salts from the land surface or unsaturated zone to water table by means of precipitationirrigation-evaporation cycles (Rajagopalan et al. 2006).

Use of perchlorate in rocket installations is found to be the major reason for perchlorate contamination of drinking water (ITRC 2005), and the present study also confirms the role of rocket installations in perchlorate contamination. Perchlorate may enter groundwater from the highly concentrated brine solution buried near rocket motor washout facilities (Flowers and Hunt 2000). The present study has proved that the major reason for drinking water contamination by perchlorate in Kerala is rocket propellant manufacturing (APEP) and rocket testing facilities (TERLS). An earlier study (Anupama et al. 2012) observed a concentration of $1.33-91.4 \mathrm{ppb}$ of perchlorate in drinking water during post-monsoon (during the year 2009) which is lower than the concentration detected in the present study. In another study by Anupama et al. (2015), perchlorate content varied from 2.76 to $7270 \mathrm{ppb}$ during pre-monsoon (in the year 2012) and is also lower than the concentrations observed in this study (BDL to 32,602.6 ppb). Anupama et al. (2015) studied the perchlorate contamination in four sites, which are not concentrated around the particular industrial site, during pre-monsoon. They did the analysis of drinking water samples from points which are located a few kilometers away from the industrial units. The present study was focused mainly around the industrial sites, and the sampling points are $500 \mathrm{~m}$ around the source at 
Table 2 Mean values of physicochemical parameters in the study area during different seasons

\begin{tabular}{lllllllllllllll}
\hline Site & Season & $\mathrm{pH}$ & $\begin{array}{l}\mathrm{EC} \\
(\mu \mathrm{S} /\end{array}$ & $\begin{array}{l}\mathrm{TDS} \\
(\mathrm{ppb})\end{array}$ & $\begin{array}{l}\mathrm{SAL} \\
(\mathrm{ppt})\end{array}$ & $\begin{array}{l}\mathrm{Cl}^{-} \\
(\mathrm{mg} / \mathrm{L})\end{array}$ & $\begin{array}{l}\mathrm{NO}_{3}^{-} \\
(\mathrm{mg} / \mathrm{L})\end{array}$ & $\begin{array}{l}\mathrm{SO}_{4}^{2-} \\
(\mathrm{mg} / \mathrm{L})\end{array}$ & $\begin{array}{l}\mathrm{Na}^{+} \\
(\mathrm{mg} / \mathrm{L})\end{array}$ & $\begin{array}{l}\mathrm{K}^{+} \\
(\mathrm{mg} / \\
\mathrm{L})\end{array}$ & $\begin{array}{l}\mathrm{Ca}^{2+} \\
(\mathrm{mg} / \mathrm{L})\end{array}$ & $\begin{array}{l}\mathrm{Mg}^{2+} \\
(\mathrm{mg} / \mathrm{L})\end{array}$ & $\begin{array}{l}\mathrm{NH}_{4}^{+} \\
(\mathrm{mg} / \mathrm{L})\end{array}$ & $\begin{array}{l}\mathrm{ClO}_{3}{ }^{-} \\
(\mu \mathrm{g} / \mathrm{L})\end{array}$ \\
\hline Site 1 & POM & 5.9 & 66.8 & 33.4 & 0.03 & 14.8 & 7.05 & 3.31 & 17.08 & 4.40 & 9.66 & 3.02 & $\mathrm{BDL}$ & 664.59 \\
& PRM & 5.8 & 60.58 & 30.3 & 0.03 & 9.48 & 7.06 & 1.38 & 11.6 & 2.68 & 15.1 & 2.7 & $\mathrm{BDL}$ & 1362 \\
& MON & 7.6 & 62.7 & 31.1 & 0.03 & 9.17 & 10.8 & 1.17 & 10.3 & 1.89 & 5.17 & 1.35 & $\mathrm{BDL}$ & 168.6 \\
Site 2 & POM & 5.97 & 445.8 & 186.0 & 0.18 & 61.01 & 61.6 & 58.7 & 105.9 & 34.6 & 27.5 & 20.4 & 112.6 & 894.0 \\
& PRM & 6.32 & 476.9 & 238.4 & 0.23 & 146.2 & 151.5 & 67.4 & 125.1 & 35.3 & 102.4 & 17.0 & 4.05 & 479.73 \\
& MON & 7.56 & 367 & 183.6 & 0.17 & 56.8 & 64.5 & 25.4 & 74.6 & 20.3 & 64.9 & 9.92 & 5.07 & $\mathrm{BDL}$ \\
Site 3 & POM & 5.2 & 44.8 & 22.40 & 0.02 & 7.29 & 4.7 & 3.58 & 8.90 & 4.38 & 4.43 & 2.33 & 0.46 & $\mathrm{BDL}$ \\
& PRM & 4.7 & 33.3 & 16.8 & 0.02 & 6.34 & 2.12 & 1.28 & 7.57 & 2.63 & 4.33 & 2.51 & $\mathrm{BDL}$ & 46.09 \\
& MON & 8.13 & 39.4 & 19.7 & 0.02 & 6.61 & 5.37 & 1.25 & 6.44 & 2.48 & 4.80 & 1.78 & 0.09 & 13.49 \\
Site 4 & POM & 6.7 & 257.4 & 128.6 & 0.12 & 4.3 & 4.51 & 51.0 & 81.5 & 18.9 & 56.5 & 1.9 & 104.8 & $\mathrm{BDL}$ \\
& PRM & 6.26 & 255.3 & 127.7 & 0.12 & 199.5 & 8.85 & 70.1 & 69.1 & 14.6 & 61.9 & 23.7 & 11.3 & 35.2 \\
& MON & 7.15 & 288.8 & 144.4 & 0.14 & 71.17 & 8.26 & 36.9 & 87.2 & 9.62 & 47.0 & 13.9 & 1.72 & 32.98 \\
Site 5 & POM & 5.4 & 141.8 & 70.8 & 0.07 & 34.4 & 13.1 & 2.92 & 34.7 & 12.7 & 6.7 & 3.52 & $\mathrm{BDL}$ & 23.9 \\
& PRM & 5.9 & 131.4 & 65.7 & 0.06 & 41.7 & 14.0 & 1.55 & 40.9 & 15.3 & 8.30 & 5.17 & $\mathrm{BDL}$ & 97.10 \\
& MON & 7.5 & 136.3 & 68.1 & 0.06 & 42.7 & 15.19 & 1.74 & 35.8 & 14.2 & 6.5 & 3.65 & 0.10 & $\mathrm{BDL}$ \\
\hline
\end{tabular}

different directions. This might be the reason for high perchlorate concentration observed in this study. In the present study, the concentration observed at APEP industrial region (maximum 32,602.6 ppb, mean $5094.87 \mathrm{ppb}$ ) is higher than in the earlier study (maximum $7270 \mathrm{ppb}$; mean $7230 \mathrm{ppb}$ ) (Anupama et al. 2015). The same trend is also observed at TERLS, i.e., high concentration in the present study (mean $468.57 \mathrm{ppb}$ ) compared to the earlier study (mean $300 \mathrm{ppb}$ ) (Table 3). This clearly shows the high concentration of perchlorate in the surrounding environment of the industries. This may be due to the slow rate of degradation along with industrial output, and this may enhance the concentration or accumulate the perchlorate in this region. Wastewater from perchlorate manufacturing companies dispersed into water bodies causes widespread perchlorate contamination (Hogue 2003). The present study also established the role of firework manufacturing units in perchlorate contamination of water bodies. Groundwater contamination due to firework manufacturing has been reported from other parts of the country (Isobe et al. 2013). Also in China, firework production and display accounts for the perchlorate contamination in groundwater, tap water, surface water and bottled water (Shi et al. 2007). The present study showed the contamination of drinking water sources nearby firework manufacturing units. At site 3 , the higher concentration was observed during monsoon, whereas at site 4 it was during post-monsoon. Site 3 is located at an elevated region and rainfall could bring down the perchlorate from the soils to aquatic systems of lower lands, whereas site 4 is located in a plain land and is surrounded by wetlands. Hence, the seasonal variation could be owed to the geography and local climatic conditions of the region.

The maximum range of perchlorate in all sites was observed during post-monsoon, whereas widespread contamination was noticed during monsoon season besides the low perchlorate values compared to other seasons. Runoff during monsoon season might have resulted in widespread contamination and dilution of the chemical. Well water samples showed more perchlorate than tap water (perchlorate remained BDL in tap water samples from majority of sites), thus proving the source of contamination as the

Table 3 Comparison of perchlorate content (ppb) with an earlier study

\begin{tabular}{|c|c|c|c|c|c|c|}
\hline & \multicolumn{3}{|l|}{ APEP } & \multicolumn{3}{|l|}{ TERLS } \\
\hline & No. of samples & Maximum value & Mean value & No. of samples & Maximum value & Mean value \\
\hline Anupama et al. (2015) & 2 & 7270 & 7230 & 2 & 300 & 300 \\
\hline The present study & 7 & $32,602.6$ & 5094.87 & 7 & 3133.05 & 468.57 \\
\hline
\end{tabular}


selected sites itself. Perchlorate contamination is found to be site dependent. At TERLS, perchlorate was detected from tap water samples also. When city water supply fails to provide water in the area, water is supplied from the TERLS water supply, which uses a large well within the rocket ground testing site, which might be the reason for the presence of perchlorate in tap water samples. No perchlorate was detected in the water samples collected from the control site in any of the seasons, and it again confirms that the perchlorate contamination is source dependent. The health safe reference dose of perchlorate in drinking water is $24.5 \mathrm{ppb}$. Above this can result in thyroid disorders. However at APEP and TERLS, perchlorate dosage in drinking water is far above $24.5 \mathrm{ppb}$ in all the seasons. Since perchlorate is exceeding the limit in all seasons, it may result in thyroid disorders in the area. The chances for thyroid disorders and abnormal growth of breast milkconsuming infants cannot be neglected (Renner 2008). In Arizona, perchlorate-contaminated Colorado River resulted in causing abnormal thyroid functions of newborns, and in California the same happened because of gestational exposure (Brechner et al. 2000; Schwartz 2001). Also perchlorate may reach vegetation, fishes, insects, mammals, etc. through water (Smith et al. 2005; Park et al. 2007; Smith et al. 2001). Perchlorate was found in fish, amphibians, aquatic insect larvae, etc. (Smith et al. 2001; Park et al. 2007). Further survey and detailed studies are needed to finalize the same in this part of the world also.

Data gaps exist on the presence of any natural perchlorate in the site. Elaborate study is essential to differentiate the natural and man-made perchlorate in all the sites. The studies on health impacts are important, and it may need further survey and other studies such as blood sample analysis and urine sample analysis. More research on perchlorate degradation using latest chemical treatment methods, which uses minimum time, has to be carried out for the drinking water supplies in the contaminated areas.

\section{Conclusion}

The present study assessed the perchlorate contamination of water resources of selected sources in Kerala. The results showed that the adjacent aquatic ecosystems of the industries which are manufacturing and using were contaminated with perchlorate. The contamination of perchlorate is found to be site dependent. Also the contamination in drinking water varied with season and source. The results indicated that rocket propellant manufacturing and consumption and fireworks manufacturing are found to be the major sources of perchlorate in Kerala. Firework manufacturing sites are located in almost all districts of Kerala. Hence, there may be a chance of widespread contamination of perchlorate in drinking water. The result of the present study is significant and urges a detailed investigation in this regard. Also elaborate research is needed to detect the thyroid disorders in this area.

Acknowledgement The financial support from DoECC, Government of Kerala, through a project is gratefully acknowledged. Also acknowledges DST-FIST and DST-PURSE, Government of India, for supporting instrumental facility. First author also acknowledges the Junior Research Fellowship from UGC, Government of India.

\section{References}

Anupama VN, Kannan K, Prajeesh PV, Rugmini S, Krishnakumar B (2012) Perchlorate, chlorate and bromate in water samples from the South-West Coast of India. Water Sci Technol: Water Supply 12(5):595-603

Anupama VN, Prajeesh GP, Krishnakumar B (2015) Surveillance of perchlorate in ground water, surface water and bottled water in Kerala, India. J Environ Health Sci Eng 13:56. doi:10.1186/ s40201-015-0213-z

ATSDR (Agency for Toxic Substances and Disease Registry) (2008) ToxFAQs for perchlorates. www.atsdr.cdc.gov/tfacts 162 . html\#bootmark04

BIS (Bureau of Indian Standards) (2012) Specification for drinking water IS 10500: 2012, New Delhi, India

Brechner RJ, Parkhurst GD, Humble WO et al (2000) Ammonium perchlorate contamination in Colorado River drinking water is associated with abnormal thyroid function in newborns in Arizona. J Occup Environ Med 42:777-782

Cheng Q, Liu F, Smith PN, Jackson WA, McMurry ST, Hooper MJ, Smith EE, Blount BC, Valentin-Blasini L, Todd AA (2008) Perchlorate distribution, excretion and depuration in Prairie Voles and Deer mice. Water Air Soil Pollut 192:127-139. doi:10.1007/s11270-008-9640-0

Dohan O, Portulano C, Basquin C, Reyna-Neyra A, Amzel LM (2007) The $\mathrm{Na}^{+} / \mathrm{I}^{-}$symporter (NIS) mediates electroneutral active transport of the environmental pollutant perchlorate. Proc Natl Acad Sci 104(51):20250-20255. doi:10.1073/pnas. 0707207104

Flowers TC, Hunt JR (2000) Long-term release of perchlorate as a potential source of groundwater contamination. In: Urbansky ET (ed) Perchlorate in the environment, chap. 14. Kluwer/Plenum, New York

Hogue C (2003) Rocket-fueled river. Chem Eng News 81:37. doi:10. 1021/cen-v081n033.p037

Hornung MW, Degitz SJ, Korte LM (2010) Inhibition of thyroid hormone release from cultured amphibian thyroid glands by methimazole, 6-propylthiouracil and perchlorate. Toxicol Sci 118(1):42-51

Isobe $\mathrm{T}$, Ogawa $\mathrm{SP}$, Sugimoto $\mathrm{R}$, Ramu $\mathrm{K}$, Sudaryanto A, Malarvannan G, Devanathan G, Ramaswamy BR, Munuswamy N, Ganesh DS, Sivakumar J, Sethuraman A, Parthasarathy V, Subramanian A, Field J, Tanabe S (2013) Perchlorate contamination of groundwater from fireworks manufacturing area in South India. Environ Monit Assess 185:5627-5637

ITRC (Interstate Technology and Regulatory Council) (2005) Perchlorate: overview of issues, status and remedial options. PERCHLORATE-1. Washington: Interstate Technology and Regulatory Council, Perchlorate Team. http://www.itrcweb.org 
Kannan K, Praamsma ML, Oldi JF, Kunisue T, Sinha RK (2009) Occurrence of perchlorate in drinking water, ground water and surface water and human saliva from India. Chemosphere $76: 22-26$

Kirk AB (2006) Environmental perchlorate: why it matters. Anal Chim Acta 567:4-12

Logan BE (1998) A review of chlorate- and perchlorate-respiring microorganisms. Bioremediat J 2(2):69-79

McLaughlin CL, Blake S, Hall T, Harman M, Kanda R, Hunt J, Rumsby PC (2011) Perchlorate in raw and drinking water sources in England and Wales. Water Environ J 25:456-465

Motzer WE (2001) Perchlorate: problems, detection and solutions. Environ Forensics 2:301-311. doi:10.1006/enfo.2001.0059

Park JW, Bradford MC, Rinchard J, Liu F, Wages M, Waters A, Kendall JR, Anderson AT, Theodorakis WC (2007) Uptake, elimination and relative distribution of perchlorate in various tissues of channel catfish. Environ Sci Technol 41:7581-7586

Rajagopalan S, Anderson TA, Fahlquist L, Rainwater KA, Ridley M, Jackson WA (2006) Widespread presence of naturally occurring perchlorate in high plains of Texas and New Mexico. Environ Sci Technol 40:3156-3162

Renner R (2008) Perchlorate and iodine: a novel focus on newborns. Environ Sci Technol. doi:10.1021/es8024758:7731

Sanchez CA, Crumps KS, Krieger RL, Khandaker NR, Gibbs JP (2005) Perchlorate and nitrate in leafy vegetables of North America. Environ Sci Technol 39(24):9391-9397

Schwartz J (2001) Gestational exposure to perchlorate is associated with measures of decreased thyroid function in a population of california neonates (masters thesis). University of California Berkeley, Berkeley

Shi Y, Zhang P, Wang Y, Shi J, Cai Y, Mou S et al (2007) Perchlorate in sewage sludge, rice, bottled water and milk collected from different areas in China. Environ Int 33:955-962

Siglin JC, Mattie DR, Dodd DE, Hilderbrandt PK, Baker WH (2000) A 90-day drinking water toxicity study in rats of the environmental contaminant ammonium perchlorate. Toxicol Sci 57:61-74

Sijimol MR, Mohan M (2014) Environmental impacts of perchlorate with special reference to fireworks: a review. Environ Monit Assess 186:7203-7210. doi:10.1007/s10661-014-3921-4

Smith NP, Theodorakis WC, Anderson AT, Kendall JR (2001) Preliminary assessment of perchlorate in ecological receptors at the Longhorn Army Ammunition Plant (LHAAP), Karnack, Texas. Ecotoxicology 10:305-313

Smith NP, Utley JS, Cox BS, Anderson AT, McMurry TS (2005) Monitoring perchlorate exposure and thyroid hormone status among raccoons inhabiting a perchlorate-contaminated site. Environ Monit Assess 102:337-347

Snyder SA, Vanderford BJ, Rexing DJ (2005) Trace analysis of bromate, chlorate, iodate and perchlorate in natural and bottled waters. Environ Sci Technol 39:4586-4593

Soldin OP, Braverman LE, Lamm SH (2001) Perchlorate clinical pharmacology and human health: a review. Ther Drug Monit 23:316-331

Srinivasan A, Viraraghavan T (2009) Perchlorate: health effects and technologies for its removal from water resources. Int $\mathbf{J}$ Environ Res Public Health 6:1418-1442. doi:10.3390/ijerph6041418

Steinmaus C, Miller MD, Smith AH (2010) Perchlorate in drinking water during pregnancy and neonatal thyroid hormone levels in California. J Occup Environ Med 52(12):1217-1224

Sugimoto R, Isobe T, Ramu K, Malarvannan G, Devanthan G, Subramanian A, Tanabe S (2012) Fireworks displays and production as a perchlorate emission source. In: Interdisciplinary studies on environmental chemistry: environmental pollution and ecotoxicology, pp 279-284

Tikkanen MW (2006) Development of a drinking water regulation for perchlorate in California. Anal Chim Acta 567:20-25

WHO (World Health Organization) (2011) Guidelines for drinkingwater quality, 4th edition. www.who.int/water_sanitation health/publications/2011/dwq.../en/ 